\title{
Ultrasound-Assisted Mild Heating Treatment Improves the Emulsifying Properties of 11S Globulins
}

\author{
Linlin Liu $\oplus^{\circledR}$, Jianhua Zeng ${ }^{\circledR}$, Bingyu Sun, Na Zhang ${ }^{\circledR}$, Yinyuan He, Yanguo Shi *® and \\ Xiuqing Zhu *
}

Key Laboratory of Grain Food and Comprehensive Processing of Grain Resource of Heilongiiang Province, Key Laboratory of Food Science and Engineering of Heilongjiang Province, College of Food Engineering, Harbin University of Commerce, Harbin 150076, China; keaiduolinlin@126.com (L.L.); foodleslie@163.com (J.Z.); sby0451@163.com (B.S.); foodzhangna@163.com (N.Z.); heyinyuan717@163.com (Y.H.)

* Correspondence: yanguosh@163.com (Y.S.); xqzhuwang@163.com (X.Z.); Tel.: +86-136-0368-1425 (Y.S.); +86-138-4510-7825 (X.Z.)

Academic Editor: Antonio Trincone

Received: 17 January 2020; Accepted: 14 February 2020; Published: 17 February 2020

\begin{abstract}
Ultrasonic technology is often used to modify proteins. Here, we investigated the effects of ultrasound alone or in combination with other heating methods on emulsifying properties and structure of glycinin (11S globulin). Structural alterations were assessed with Sodium dodecyl sulphate-polyacrylamide gel electrophoresis (SDS-PAGE), intrinsic fluorescence spectroscopy, ultraviolet (UV) absorption spectroscopy, and Fourier transform infrared (FTIR) spectroscopy. The size distribution and zeta-potential of $11 \mathrm{~S}$ globulin were evaluated with a particle size analyzer. An SDS-PAGE analysis showed no remarkable changes in the primary structure of $11 \mathrm{~S}$ globulin. Ultrasound treatment disrupted the 11S globulin aggregates into small particles with uniform size, narrowed their distribution and increased their surface charge density. Fluorescent spectroscopy and second-derivative UV spectroscopy revealed that ultrasound coupled with heating induced partial unfolding of 11S globulin, increasing its flexibility and hydrophobicity. FTIR further showed that the random coil and $\alpha$-helix contents were higher while $\beta$-turn and $\beta$-sheet contents were lower in ultrasound combined with heating group compared to the control group. Consequently, the oil-water interface entirely distributed protein and reduced the surface tension. Moreover, ultrasound combined with heating at $60^{\circ} \mathrm{C}$ increased the emulsifying activity index and emulsifying stability index of $11 \mathrm{~S}$ globulins by 6.49 -folds and 2.90-folds, respectively. These findings suggest that ultrasound combined with mild heating modifies the emulsification properties of $11 \mathrm{~S}$ globulin.
\end{abstract}

Keywords: ultrasound; mild heating; structure; emulsifying property; glycinin

\section{Introduction}

Proteins extracted from soybeans are essential ingredients for industrial food products such as beverages and nutraceuticals because they are affordable, with health benefits [1-3]. However, untreated soy proteins are not readily applicable because of limited surface-active properties (e.g., emulsifying property) and solubility. Moreover, in untreated state, soy proteins have quaternary and tertiary compact structures [3-5]. It is, therefore, imperative to modify native structures of soy proteins to increase their solubility and emulsification properties.

Protein functions are intrinsically linked to protein structures. Previously, highly sensitive processing technologies have been developed for effective modification of soybean proteins [6-8]. Among them, ultrasonic technology has been found to be a safe and environmentally friendly method of modifying proteins as it does not involve chemical treatments. This method leverages on the cavitation phenomenon at a frequency which is beyond the threshold of human hearing $(>16 \mathrm{kHz})$ and is currently 
applied in food industry [9-11]. High-intensity ultrasound reduces the particle size of proteins. In soy protein isolates, it enhances the foaming properties, emulsion stability, and emulsifying activity of soy protein isolates or soybean glycinin (11S globulin) $[5,10]$. Hu et al. revealed that ultrasonic technology improved the fluid character and solubility of soy protein isolate dispersions [12]. This was attributed to the reduction of intermolecular interactions and partial unfolding. Also, O'Sullivan et al. [13] observed that ultrasound treatment reduced the particle size, improved solubility (pea and soy protein isolates) and the emulsification characteristics of egg white, bovine gelatin, and pea protein isolates.

However, in industrial food production, ultrasonication alone is time and energy-consuming; hence, less efficient. Researchers have proposed that combining ultrasound techniques with other modification techniques may overcome these limitations $[9,13,14]$. A recent study reported that ultrasound combined with transglutaminase treatment significantly improved the gelling properties of whey protein [15]. Ultrasound-assisted alkali or acid treatment accelerates enzymatic hydrolysis dissociation and protein solubility by unfolding and exposing hydrophobic groups. However, additional costs and safety risks limit its large-scale utilization $[14,16]$.

Heating is a traditionally safe technique that improves protein functions. Of note, it induces multiple desirable structural changes in proteins [1]. Several studies have characterized the functional properties of protein-containing foods that have been structurally modified with thermal processing technologies $[17,18]$. However, the efficiency of protein modification using ultrasound in combination with heating has not been fully characterized. Ultrasound treatments increase the sensitivity of protein molecules to heating temperature. Based on the foregoing discussion, understanding the functional properties of soy proteins treated with ultrasound alone or in combination with heating is essential for its optimal industrial utility.

The $11 \mathrm{~S}$ globulins are major storage proteins in soybeans accounting for nearly $40-60 \%$ of the total seed endosperm protein. They, therefore, contribute to the functional properties and nutritional quality of soybean proteins [3]. In this study, the effect of ultrasound alone or in combination with heating $\left(50\right.$ and $60^{\circ} \mathrm{C}$ ) on the structural and functional properties of soy proteins was evaluated. Structural alterations were examined by intrinsic fluorescence spectroscopy, Sodium dodecyl sulfate -polyacrylamide gel electrophoresis (SDS-PAGE), ultraviolet (UV) absorption spectroscopy, and Fourier transform infrared (FTIR) spectroscopy. Size distribution and zeta-potential were evaluated using a particle size analyzer. The findings of this study show that ultrasound combined with heat treatment improves the functionality of $11 S$ globulins-containing foods.

\section{Results and Discussion}

\subsection{Structural Characterization}

\subsubsection{SDS-PAGE Analysis}

Samples concurrently exposed to mild heating and ultrasound, mild heating or ultrasound alone were characterized by nonreductive SDS-PAGE and SDS-PAGE to analyze the disassociation-and-association behavior (Figure 1) [19]. Notably, the protein electrophoresis pattern was similar between the groups, suggesting that ultrasound and mild heating did not modify $11 S$ globulin primary structure. This result is consistent with that reported previously [19-21]. Incremental increases in heating temperature caused more soluble aggregates lacking Bs subunits to form appeared above the separation gel (Figure 1a). This showed that high-temperature heating increased protein aggregation and decreased Bs subunits in the protein. Whereas ultrasound treatment reduced the formation of aggregates, ultrasound combined with mild heating completely prevented the formation of aggregates while increasing the Bs subunits content (Figure 1b). This suggests that the treatments disrupted the protein aggregates into small particles via the cavitation effects. Moreover, in the nonreductive SDS-PAGE analysis, ultrasound treatment increased the number of dimers formed by the proteins, indicating that the formation of aggregates induced by heating was due to noncovalent interactions (e.g., electrostatic and hydrophobic interaction) rather than covalent bonds (such as, 
intermolecular disulfide) between protein molecules. Figure 1b shows that addition of 2-ME did not induce dimers formation, indicating that heating caused dimers formation through disulfide bonds. The structural characteristics were further investigated with fluorescence spectra, UV spectra, and FTIR techniques.

a

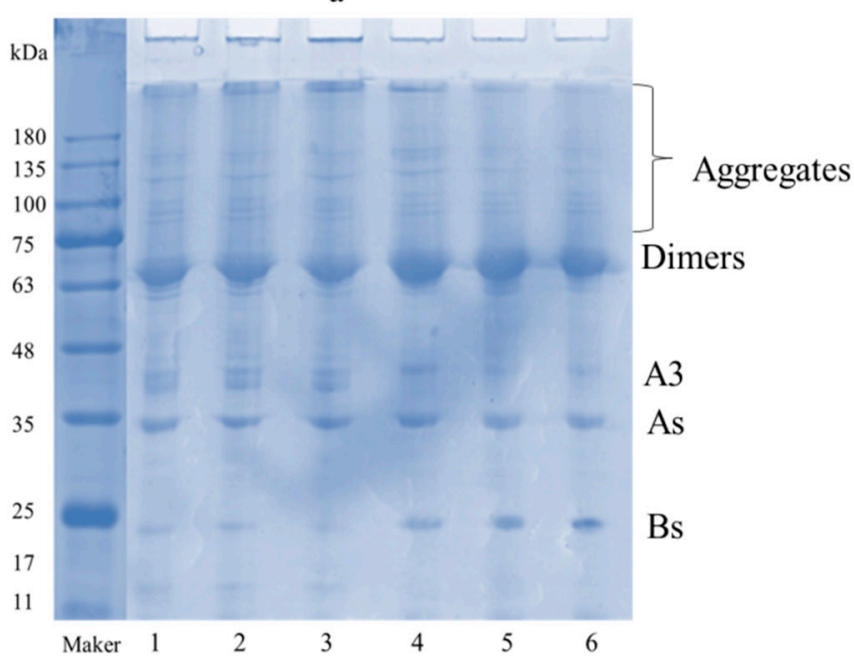

b

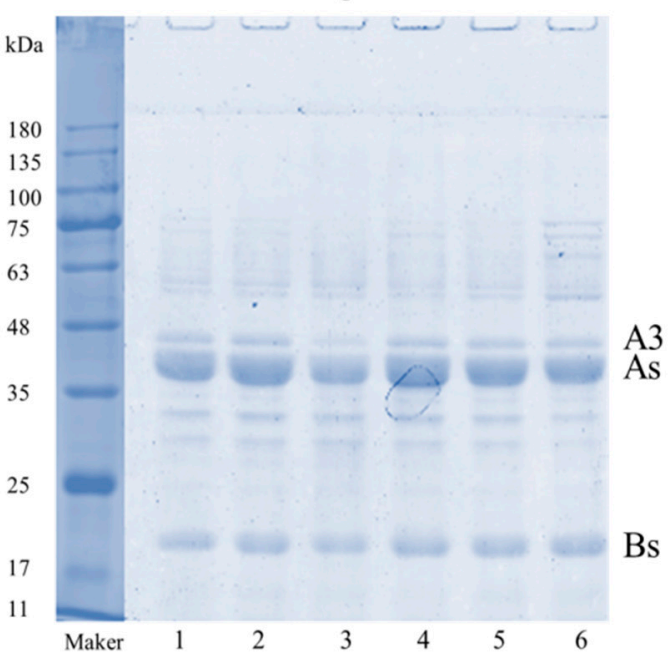

Figure 1. Non-reductive SDS-PAGE electrophoresis profile (a): 1-6 without 2-mercaptoethanol (2-ME) and SDS-PAGE electrophoresis profile (b): 1-6 with 2-ME. 1-Control, 2-50 ${ }^{\circ} \mathrm{C}, 3-60{ }^{\circ} \mathrm{C}, 4$-Ultrasound, 5-Ultrasound- $50{ }^{\circ} \mathrm{C}$, 6-Ultrasound- $60{ }^{\circ} \mathrm{C}$.

\subsubsection{Fluorescence Spectra Analysis}

Changes in the tertiary structure of $11 \mathrm{~S}$ globulins after ultrasound treatments were investigated by fluorescence spectroscopy (Figure 2a). In the control samples, the maximum emission wavelength $\left(\lambda_{\max }\right)$ was $337 \mathrm{~nm}$. For $11 \mathrm{~S}$ globulins treated with heating alone $\left(50\right.$ and $\left.60{ }^{\circ} \mathrm{C}\right), \lambda_{\max }$ was not changed but the fluorescence intensity of these samples was higher than that of the control group. As shown in Figure 2a, the fluorescence intensity of $11 \mathrm{~S}$ globulins treated at $60^{\circ} \mathrm{C}$ was markedly higher than that of $11 \mathrm{~S}$ globulins treated at $50{ }^{\circ} \mathrm{C}$. With an incremental increase of the heating temperature, the protein unfold increased and more chromophores were exposed, which elevated the fluorescence intensity. The wavelength of protein samples exposed to ultrasound or ultrasound combined with heating $\left(50\right.$ and $60{ }^{\circ} \mathrm{C}$ ) showed a blue shift, accompanied by a marked increase in the fluorescence intensity. This indicated that these treatments disrupted the three-dimensional structure of $11 \mathrm{~S}$ globulin protein, causing protein unfolding and shifting of hydrophobic groups in the protein towards a more hydrophobic environment (increased hydrophobicity) [1,10]. Similar blue shifts accompanied with an increase in fluorescence intensity were also reported in soybean protein isolates treated with ultrasound-assisted mild heating [1]. Wei et al. [22] stated that the blue shifts in the $\lambda_{\max }$ reflect a phenomenon where the previously exposed hydrophobic groups of soybean protein are buried into the interior of the modified protein. 

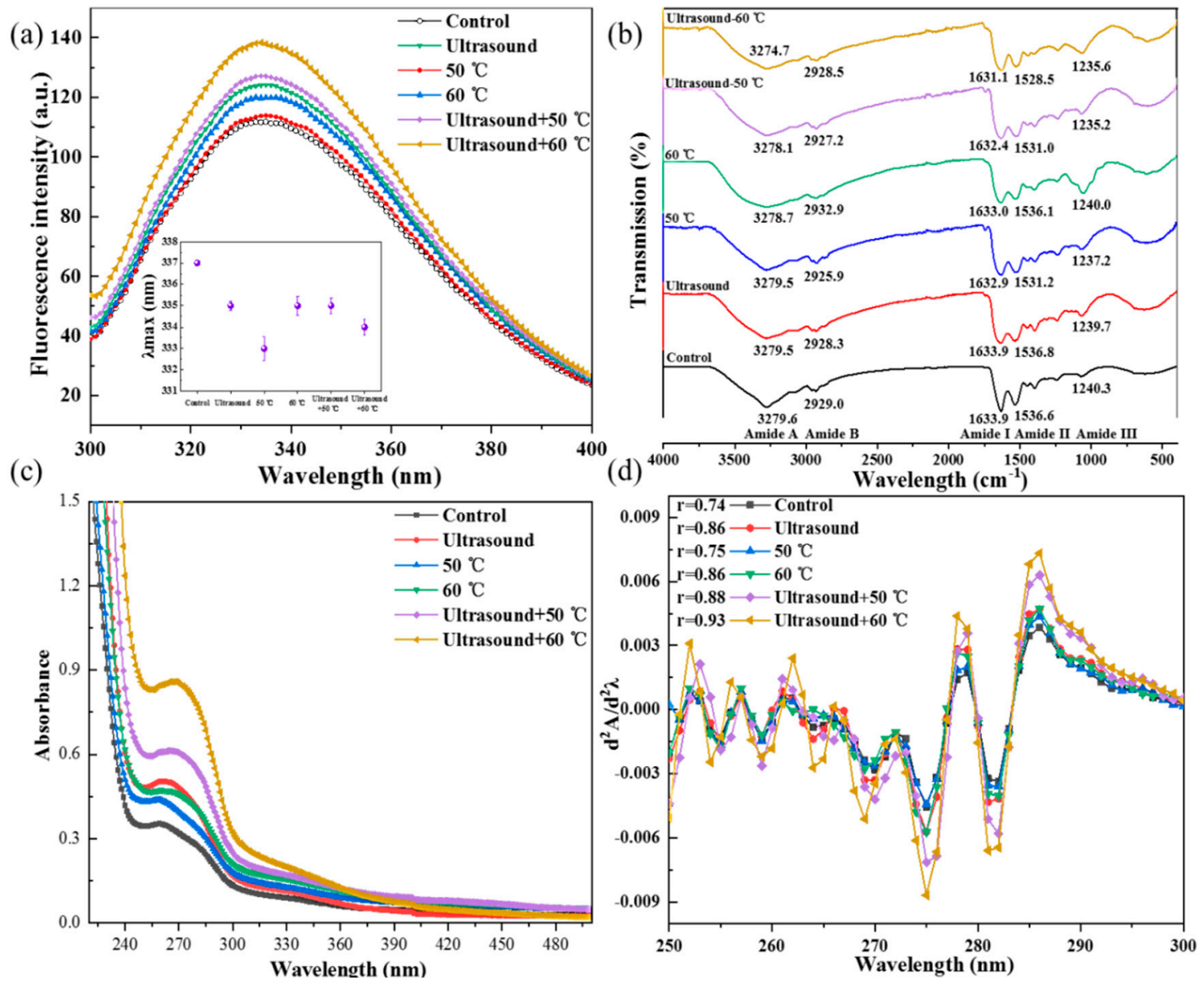

Figure 2. Effect of mild heating combined with ultrasound and ultrasound alone on the structure of 11S (a) Intrinsic fluorescence spectra, (b) Changes in FTIR, (c) UV spectra, (d) Second-derivative UV spectra.

\subsubsection{UV Spectra Analysis}

The absorbance intensity of 11S globulins exposed to mild heating or ultrasound combined with mild heating increased significantly coupled with a redshift at the maximum absorbance wavelength $(p<0.05)$ compared with the control (Figure 2c). This may be ascribed to the exposure of buried hydrophobic groups and chromophores following structure unfolding [23]. The second-derivative UV spectroscopy is highly sensitive to alterations in the tertiary structure of protein molecules and can be used to delineate the contributions of three aromatic amino acid residues (Phe, Tyr, and Trp) [23]. In this study, the second-derivative spectrum of $11 \mathrm{~S}$ globulin presented two positive peaks at 287 and $296 \mathrm{~nm}$ and two negative peaks at 284 and $292.5 \mathrm{~nm}$ (Figure 2d). Similar results were reported by Jiang et al. [24]. The peak at 270-285 nm regions and above $290 \mathrm{~nm}$ was attributed to the absorbance of Tyr, and Trp residues [23]. A continuous red shift of bands in the regions with Tyr and Trp residues after ultrasound combined with heating $\left(50\right.$ and $\left.60^{\circ} \mathrm{C}\right)$ indicated that the protein underwent partial unfolding and more Tyr/Trp residues moved to the hydrophobic region [23]. The amplitude of the derivative spectral bands, obtained by calculating the ratio $(r=a / b)$ of the two peak-to-trough values (Figure 2d), was used as a sensitive probe to predict the polarity of Tyr residues [25]. Samples exposed to ultrasound-assisted heating showed a slow increase in $\mathrm{r}$ values from 0.74 (control) to $0.75\left(50{ }^{\circ} \mathrm{C}\right)$, $0.86\left(60^{\circ} \mathrm{C}\right), 0.88$ (ultrasound $-50^{\circ} \mathrm{C}$ ) to 0.93 (ultrasound $-60^{\circ} \mathrm{C}$ ). This indicated that with an increase in energy input, more Tyr residues moved to nonpolar regions because of unfolding of the protein tertiary structure [25]. The second-derivative UV results were consistent with the fluorescence spectrum analysis, showing that ultrasound-assisted mild heating induced structural unfolding in 11S proteins. Jin et al. [23] noted that exposure of $\beta$-conglycinin to high pressure exhibited a similar redshift and a 
decrease in $r$ value, which were attributed to the shifting of Tyr residues into the hydrophobic regions following protein unfolding.

\subsubsection{FTIR Analysis}

FTIR is a method used to evaluate the secondary structure of proteins and polypeptides. In this technique, repeat subunits results in nine characteristic IR absorbance bands, marked as amide A, B, I, II, III, IV, V, VI, and VII [26] (Figure 2b).

In the present study, the FTIR of samples exposed to ultrasound alone or in combination with mild heating exhibited similar peak shapes but varying absorbance intensities (Figure $2 b$ ). The intensity of all absorbance peaks was higher in treated $11 \mathrm{~S}$ globulins samples than in control samples, excluding amide $\mathrm{A}$ band, which corresponded to the stretching vibration of the $\mathrm{OH}$ groups and $\mathrm{NH}$ stretching from 3400 to $3440 \mathrm{~cm}^{-1}$. Once the CO-NH groups were joined by hydrogen bonds, the position moved to lower frequencies close to $3300 \mathrm{~cm}^{-1}$. The amide A band of the samples subjected to ultrasound-assisted mild heating was lower than that of the control samples, suggesting that more $\mathrm{NH}$ groups in samples were involved in hydrogen bonding [27]. There were more $\alpha$-helix structures in the samples exposed to ultrasound-assisted mild heating than in control samples. The amide B peaks in the samples ranged from 2925.9 to $2932.9 \mathrm{~cm}^{-1}$, which corresponded to hydrophobic interactions caused by $\mathrm{CH}$ stretching [28] (Figure 2b).

The peaks ranging from 1633.9 to $1631.1 \mathrm{~cm}^{-1}$ corresponded to amide I $\left(1600-1700 \mathrm{~cm}^{-1}\right)$, assisted with the CO stretching vibrational frequency [26]. The absorbance peaks of the treated 11S globulins were lower compared to the control group11S globulins, indicating the formation of hydrogen bonds between $\mathrm{NH}$ and $\mathrm{CO}$ formed $\alpha$-helix [27]. A similar phenomenon was observed in the amide II band of $11 \mathrm{~S}$ globulin samples (1536.6 to $1528.5 \mathrm{~cm}^{-1}$ ), which was attributed to NH in-plane bending and the $\mathrm{CN}$ stretching vibrations. Similar results were obtained for amide A band. Treatment of $11 \mathrm{~S}$ globulins formed amide III bands ranging from 1240.3 to $1235.6 \mathrm{~cm}^{-1}$, due to $\mathrm{CN}$ stretching, $\mathrm{NH}$ in-plane bending from amide linkages and $\mathrm{CH}_{2}$ wagging vibrations (Figure $2 b$ ).

The amide I and II absorbance and vibration frequencies are strongly and positively correlated with the secondary structure components [28]. Herein, the amide I and II peaks of 11 S globulins exposed to ultrasound combined with mild heating had a lower frequency compared to the control samples, ultrasound alone, and mild heating alone, indicating loss of the higher structure due to combined treatment. The combined treatment of $11 \mathrm{~S}$ globulins yielded fewer intermolecular crosslinks and higher flexibility, which matched with the electrophoresis pattern, intrinsic fluorescence, and UV spectrum results.

The curve-fitting method was employed to characterize alterations in secondary structure of $11 \mathrm{~S}$ globulins. The random coil and $\alpha$-helix were remarkably $(p<0.05)$ higher in the treated $11 \mathrm{~S}$ globulins compared to the control samples (Figure 3). Moreover, mild heating or ultrasound treatments decreased $\beta$-sheet and $\beta$-turn content. Tang et al. [29] and Ren et al. [30] found that ultrasound treatment boosted the $\alpha$-helix content. It has also been reported that ultrasound treatment increases the $\alpha$-helix content in bovine serum albumin (BSA) aggregates and decreases $\beta$-sheet [31]. These results suggest that heating or ultrasound treatment disrupts and weakens the interactions between protein molecules. These findings are in agreement with the results of the intrinsic fluorescence spectrum and UV spectrum. Jin et al. [32] found that ultrasound treating decreased the $\alpha$-helix content and increased the $\beta$-Sheet content in proteins. In contrast, Xiong et al. [33] found that ultrasound treatment did not change the secondary structure of ovalbumin. These discrepancies may be ascribed to protein-specific properties and ultrasound-treatment conditions. In the current study, the lowest $\beta$-sheet content and the highest random coil content were affected by ultrasound. However, mild heating combined with ultrasound treatment increased the $\beta$-Sheet content, which also led to the loss of random coil. The loss of random coil reflected re-aggregation of smallest particles into media particles, which matched the results of size distribution. 


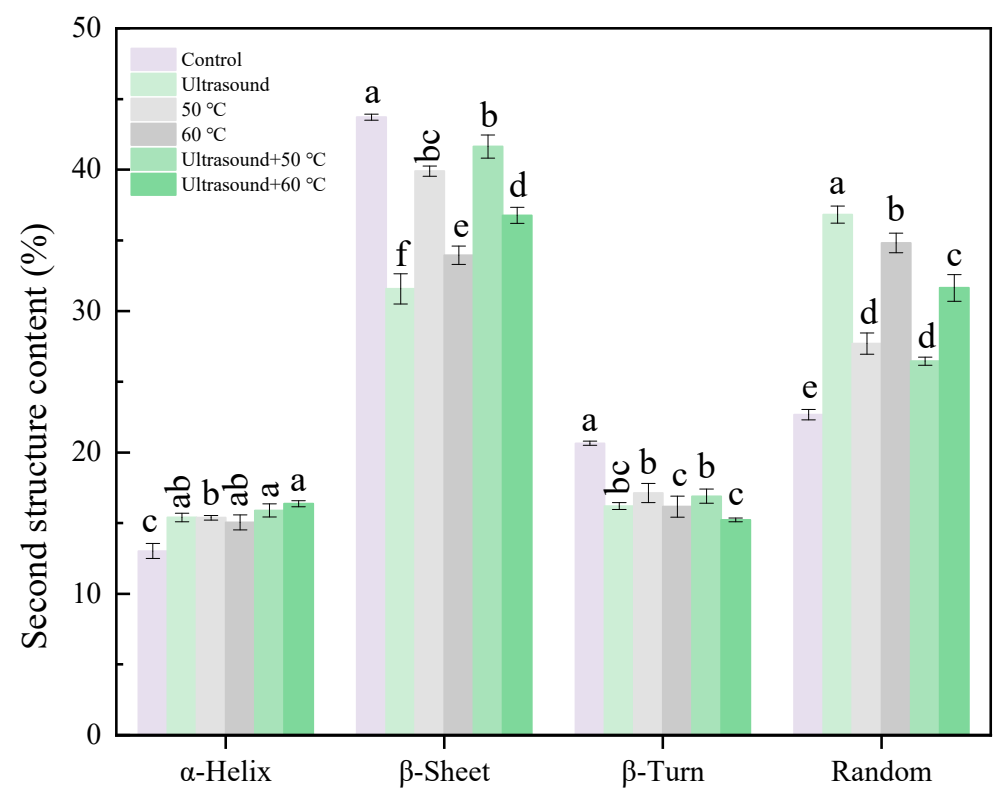

Figure 3. Secondary structure contents of $11 S$ globulin after different treatments analyzed by curve-fitting. Note: Values with the same superscript letters are not significantly different $(p<$ 0.05, RM ANOVA, Duncan test).

\subsection{Zeta Potential and Particle Size Distribution}

The samples showed a broad particle distribution with the main peak of about $100 \mathrm{~nm}$ (Figure 4a). The particles size was negligible, being less than $100 \mathrm{~nm}$ (Figure $4 \mathrm{~b}$ ). The relationship between two identical populations was 1:1000 $(v / v)$ in the volume distribution, and 1:1,000,000 in the intensity size distribution.

The average particle size of the control and treated $11 S$ globulins was $8 \mathrm{~nm}$, which corresponded to promoter homo trimeric of $11 \mathrm{~S}$ globulin $(9.5 \mathrm{~nm} \times 9.5 \mathrm{~nm} \times 4.0 \mathrm{~nm})$ [34]. The particle size was larger in treated $11 \mathrm{~S}$ globulins than in the control samples. Heating at $60^{\circ} \mathrm{C}$ markedly increased the protein size by decreasing aggregation (Figure 4c), whereas ultrasound treatment decreased the particle size and increased the protein size. Ultrasound combined with mild heating decreased the particle size by disrupting aggregation. Heating increased the molecular weight which may enhance the probability of the particles being attacked by the cavitation effects. Indeed, the soluble aggregates at 10,000 $\mathrm{nm}$ sizes were broken into small particles. Morales et al. [5] observed that simultaneous ultrasound and heating treatment decreased the particle size of soybean proteins. However, the particle size of $11 \mathrm{~S}$ globulins exposed to ultrasound heated at $50^{\circ} \mathrm{C}$ was larger than those heated at $50^{\circ} \mathrm{C}$. Changes in protein particle sizes are influenced by collision and soluble aggregate formation through noncovalent interactions (e.g., hydrophobic interaction) [35]. Several studies found that ultrasound treatment enlarged the particle size of egg proteins and bovine serum albumin by increasing hydrophobic interactions [35-37]. Herein, the combined treatment reduced the particle size into medium-size, resulting in a smaller polydispersity index (PDI). A PDI value greater than 1 indicates that the sample has a broad size distribution. (Figure 4c). This suggests that the particle distribution range of $11 \mathrm{~S}$ globulin dispersion was reduced and the dispersion of the $11 \mathrm{~S}$ globulins particles in water was enhanced [38]. These findings are in agreement with those of FTIR, SDS-PAGE and emulsion analyses.

Zeta potential indicates the stability of a system. A higher zeta potential with stronger repulsive forces between protein particles inhibits the collision and aggregation. The dispersion and aggregation of $11 \mathrm{~S}$ globulin solutions are determined on the basis of effective surface charge $[31,35]$. In the present study, all samples exhibited negative zeta potentials (Figure $4 \mathrm{~d}$ ), suggesting high density of negatively-charged amino acid residues on the protein surface. Notably, heating decreased the absolute zeta potential of $11 S$ globulin but ultrasound combined with heating produced opposite 
effects. Similar results have been reported for BSA [31] and protein isolates from black beans [35]. Combined treatment increased the negative charge on the protein surface, indicating that solution stability was improved by the cavitation effects, which disrupted existing aggregates and strengthened electrostatic repulsions, hence inhibiting further aggregation. This enhanced the solubility of $11 \mathrm{~S}$ globulin, improving emulsion properties.
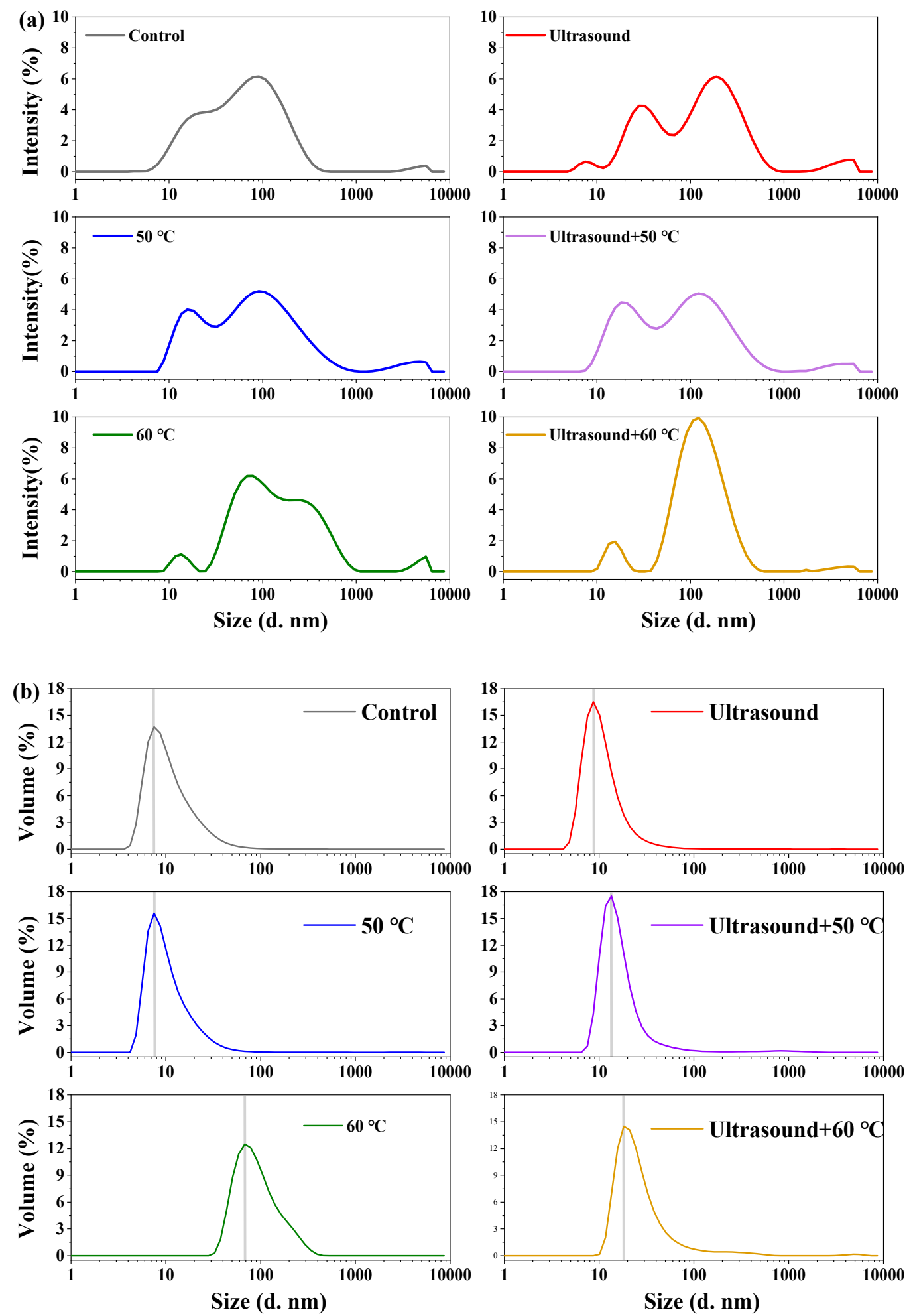

Figure 4. Cont. 

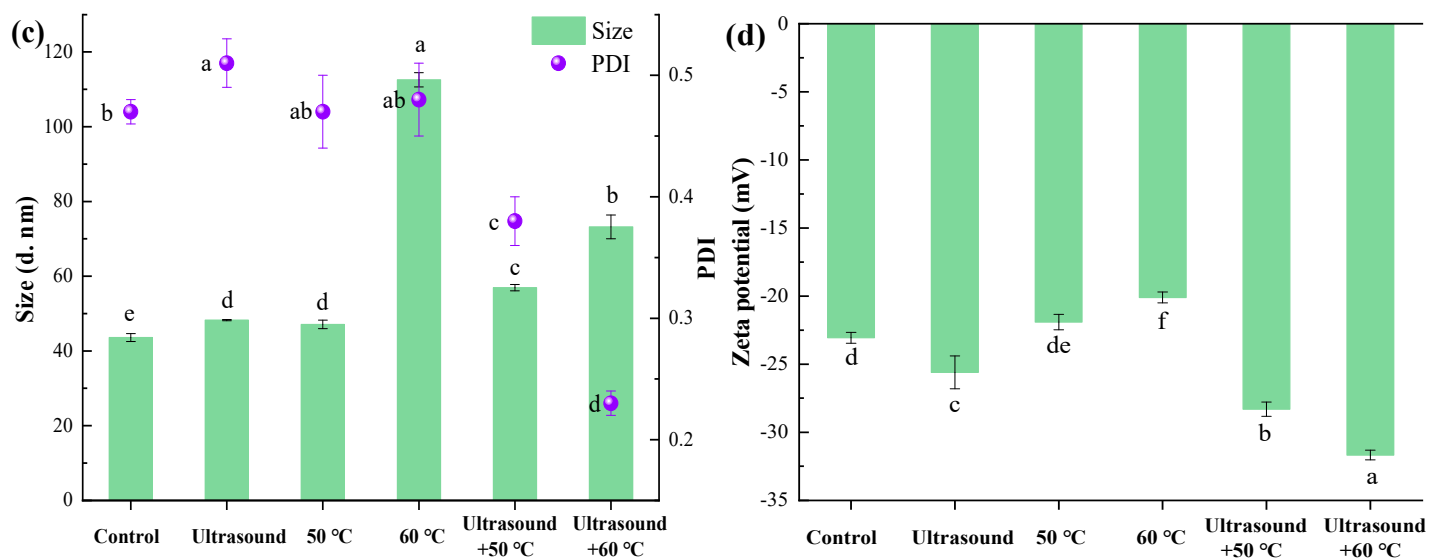

Figure 4. Zeta potential and particle size distribution of $11 \mathrm{~S}$ (a): Intensity\% distribution; (b): Volume\% distribution; (c): Value of size and PDI; (d): Zeta potential) ( $p<0.05$, RM ANOVA, Duncan test).

\subsection{Protein Flexibility Analysis}

The flexibility of a protein structure regulates its surface activity and emulsification $[39,40]$. The molecular flexibility of a protein can be detected using the protease digestion method [41] and presented as the comparative motion of different structural intervals in proteins or the amino acid residue rearrangement rate in polypeptide chains [40]. Flexibilities of proteins performing the same catalytic activity seem to be about the same at their temperature optima. But rigid thermostable proteins reach the flexibility of thennolabile proteins at higher temperatures [40].

The flexibility of $11 \mathrm{~S}$ globulins subjected to ultrasound treatment alone or in combination with mild heating was higher than of the control group (Figure 5), indicating that heating unfolded 11S globulin protein molecules. This was basically achieved by cavitation and heat effects on the tertiary and quaternary structures of $11 \mathrm{~S}$ globulins, which disrupt non-covalent bond cleavage, thus destroying the rigid structure inside the protein. As a result, the protein can be easily broken as the temperature increases [39]. Previous studies have suggested that the globulin sensitivity to protease digestion is closely associated with level of protein unfolding level [40].

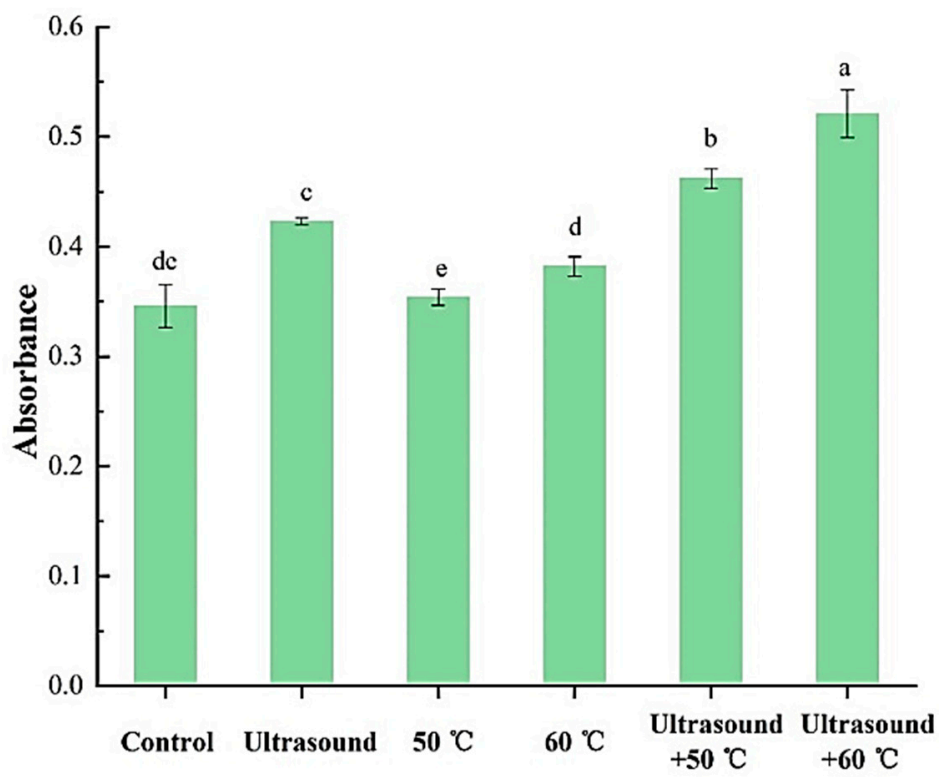

Figure 5. Effects of ultrasound with or without mild heating treatments on the flexibility of 11S globulin $(p<0.05$, RM ANOVA, Duncan test). 


\subsection{Impact of Ultrasound Treatment on Emulsifying Properties of $11 S$ Globulin}

Our results show that mild heating, mild heating combined with ultrasound, and ultrasound treatments improved emulsifying activity index (EAI) (Figure 6a). This is because ultrasound treatments increased solubility, flexibility, and hydrophobicity of the protein by changing its structure. Thus, the adsorption rate at the oil-water interface was effectively improved (Figure 6b). The EAI values of ultrasound samples exhibited were higher value than that of those heated $11 S$ globulin. This may be explained by the fact that ultrasound treatments increased flexibility and hydrophobicity, which improved protein molecule absorption at the water-oil interface and fewer free protein in the aqueous phase of emulsions. Similar phenomena have been observed in the emulsion properties of other proteins, such as peanut protein isolates [21], black bean protein isolates 40), faba bean (Vicia faba L.) protein, and myofibrillar proteins [20]. In this study, ultrasound-assisted mild heating improved EAI by triggering the formation of uniform-size protein nanoparticles (Figure 6a). Uniform-sized protein nanoparticles have been shown to enhance emulsion properties [42], making such proteins effective drug delivery systems and vaccine adjuvants [42]. Uniform-sized protein nanoparticles also improve the water holding capacity and gel strength of proteins [43].
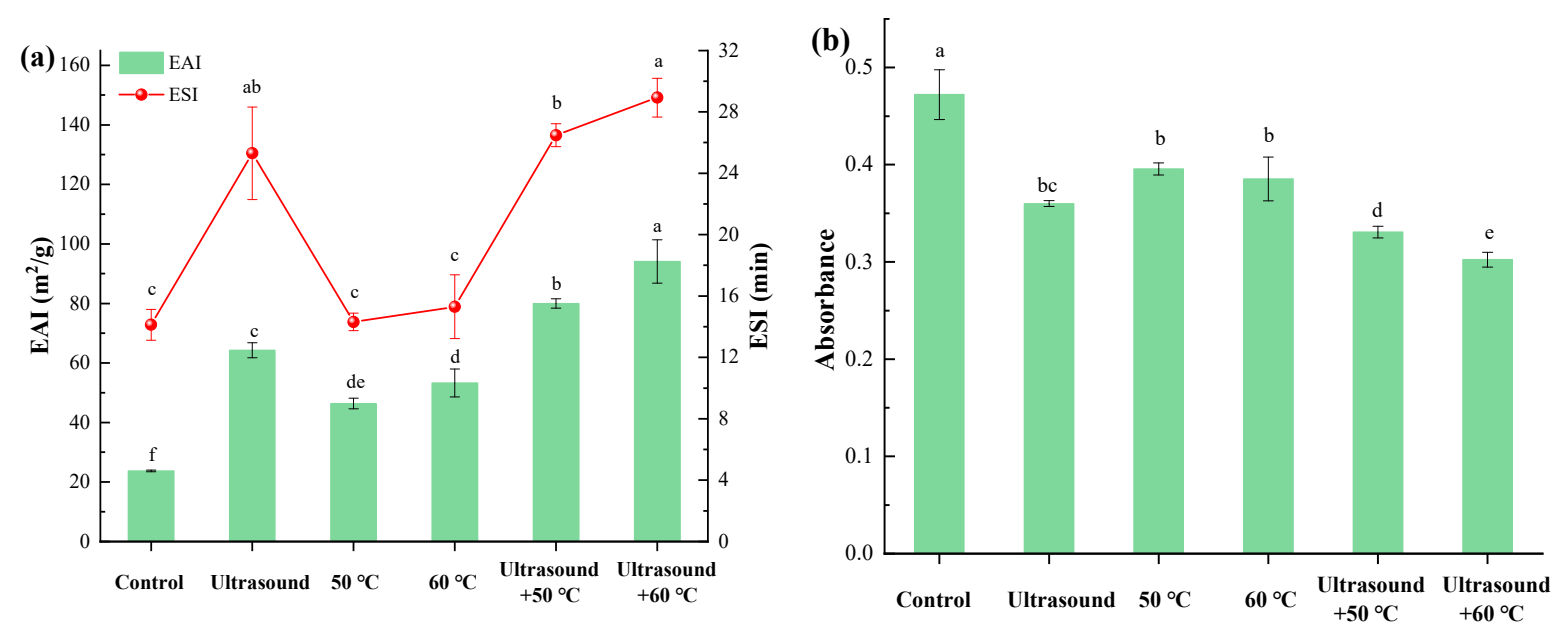

Figure 6. Effects of mild heating, mild heating combined with ultrasound and ultrasound treatments on emulsifying properties of $11 \mathrm{~S}$ globulin (a) and free protein (b) $(p<0.05$, RM ANOVA, Duncan test).

The thermodynamic properties and stability of $11 \mathrm{~S}$ globulin emulsions are influenced by flocculation, aggregation, and coalescence of emulsion droplets [20]. In this study, the changes in emulsion stability index (ESI) were similar to variations in EAI (Figure 6a) and were strongly enhanced by ultrasound or combined treatment. This is because ultrasound treatment increased the density charge on the protein surface, structural flexibility, hydrophobicity, and uniformity of particles sizes. Similar results have been reported in myofibrillar protein [20] and peanut protein isolates [21].

\subsection{Optical Microscopy Analysis of Emulsions}

To further understand the relationship between the protein particle characteristics and emulsion properties, the micro-topography of the treated and untreated samples was examined at the same magnification $(400 \times)$. The emulsion prepared from control samples (a) exhibited flocculation and had the largest droplets (Figure 7). This instability was ascribed to the poor protein flexibility and solubility, and the broad size particle distribution which decreases emulsification at the oil-water interface. Notably, mild heating $(c, d)$, ultrasound treatments $(b)$ or combined treatment $(e, f)$ decreased the size of oil droplets and increased the uniformity of particles distribution. This phenomenon implies that the emulsifier was distributed on the oil-water interface, which improved the structural flexibility, increased the charge density and size uniformity of protein particles. 

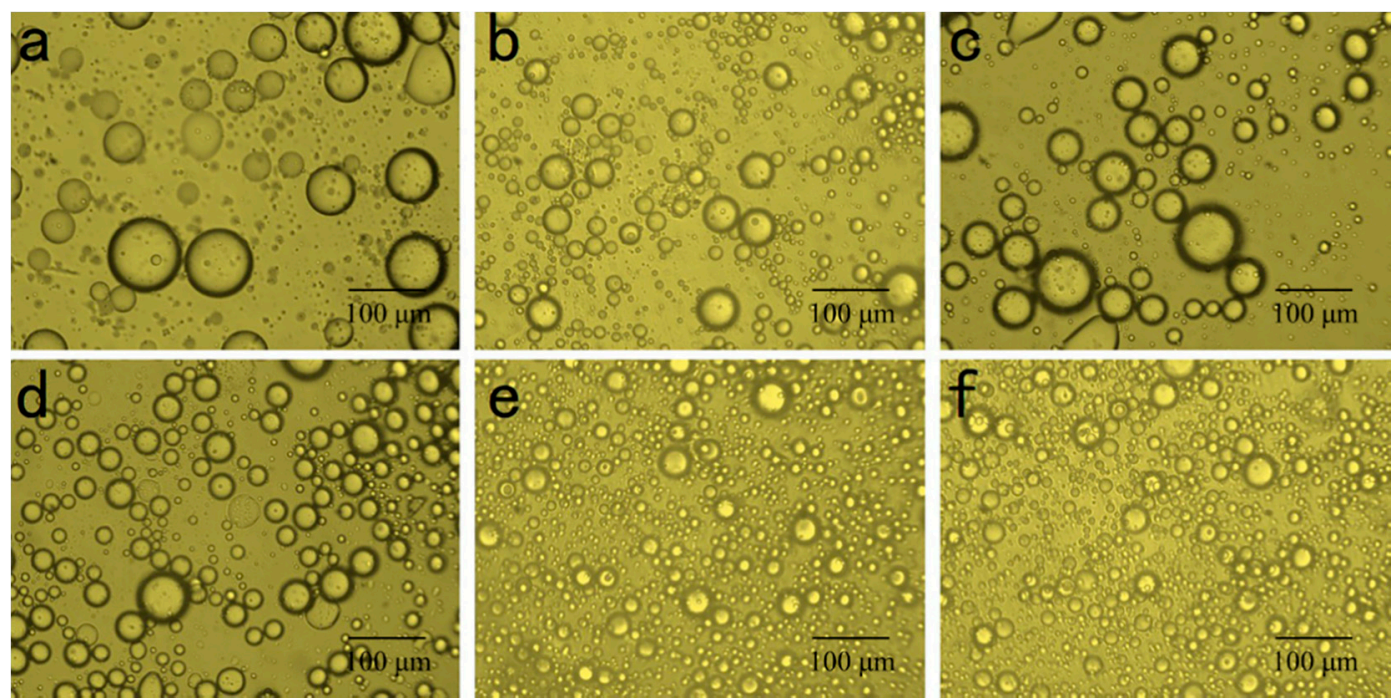

Figure 7. Optical photomicrographs of emulsions of $11 \mathrm{~S}$ globulin exposed to mild heating (c) $50{ }^{\circ} \mathrm{C}$, (d) $60{ }^{\circ} \mathrm{C}$, mild heating combined with ultrasound (e) Ultrasound-50 ${ }^{\circ} \mathrm{C}$; (f) Ultrasound-60 ${ }^{\circ} \mathrm{C}$, (b) ultrasound alone and (a) untreated $11 \mathrm{~S}$ globulin as control.

\section{Materials and Methods}

\subsection{Materials}

Soybean meal devoid of fat (protein 51.2\%) was obtained from Hexu Food Co., Ltd. (Heilongjiang, China). Soybean oil was procured from Beidahuang Grain Group Co., Ltd. (Harbin, China). 8-Anilino-1-naphthalenesulfonate (ANS), 5,5-dithio-bis (2-nitrobenzoic acid) (DTNB), n-hexane, sodium dodecyl sulphate and trypsin $(16830 \mathrm{U} / \mathrm{g})$ were obtained from Sigma (St. Louis, MO, USA). All the chemicals were used in the present study were of analytical grade quality.

\subsection{Preparation of $11 S$ Fraction}

The alkaline extraction and acid precipitation technique described by Johnson et al. was used to isolate the $11 \mathrm{~S}$ globulin fractions [44]. Briefly, defatted cold-pressed soybean meal was dispersed in Tris- $\mathrm{HCl}$ buffer $(\mathrm{pH} 8.5,0.05 \mathrm{M})$ followed by vibration extraction at $50^{\circ} \mathrm{C}$ for $1 \mathrm{~h}$. The extract was centrifuged at $4400 \times \mathrm{g}$ for $15 \mathrm{~min}$. Afterwards, the $\mathrm{pH}$ of the extract solutions was adjusted to 6.4 using $2 \mathrm{M} \mathrm{HCl}$ and allowed to stand for $30 \mathrm{~min}$ at $25^{\circ} \mathrm{C}$ to precipitate the proteins. The extracts were centrifuged at $4400 \times \mathrm{g}$ for $15 \mathrm{~min}$ and dissolved in deionized water with a $\mathrm{pH}$ of 7.0 (adjusted using 2 $\mathrm{M} \mathrm{NaOH})$. Finally, the samples were freeze-dried.

\subsection{Ultrasound and Mild Heating of $11 S$}

The freeze-dried 11S globulins were solubilized to a concentration of $10 \mathrm{mg} / \mathrm{mL}(w / v)$, then treated with either ultrasonic or mild heating. For ultrasound-assisted mild heating, the samples were maintained in a water bath at 50 and $60^{\circ} \mathrm{C}$ while being treated by ultrasonic energy at $20 \mathrm{kHz}$ at 240 W for 30 min (NingBo Scientz Biotechnology Co., Ltd., Ningbo, China). For ultrasonic heating alone, samples were maintained at $25^{\circ} \mathrm{C}$ while being treated with ultrasonic energy of $20 \mathrm{kHz}$ at $240 \mathrm{~W}$ for 30 min. For mild-heating, the samples were maintained in a water bath with a temperature of 50 and 60 ${ }^{\circ} \mathrm{C}$ for $30 \mathrm{~min}$. The control group samples were not exposed to any treatment.

\subsection{Emulsifying Capacity Index}

The ESI and EAI of protein samples were determined by dissolving the samples in phosphate-buffered solution (PBS, $10 \mathrm{mM}, \mathrm{pH} 7.2)$ to achieve a protein concentration of $50 \mathrm{mg} / \mathrm{mL}(w / v)$. Aliquots of $15 \mathrm{~mL}$ protein solution were homogenized with $5 \mathrm{~mL}$ soybean oil with an ultra-turrax 
at $10,142 \times g$ for $1 \mathrm{~min}$. An amount of $50 \mu \mathrm{L}$ of the emulsion was collected from the bottom of the homogenized emulsion immediately at $0 \mathrm{~min}$ and after $10 \mathrm{~min}$, then diluted in $5 \mathrm{~mL}$ of $1 \mathrm{mg} / \mathrm{mL}$ $(w / v)$ sodium dodecyl sulfate (SDS) solution. After vortexing for $5 \mathrm{~s}$, the absorbance of the diluted emulsions was measured at $500 \mathrm{~nm}$ using a spectrophotometer [45]. The ESI and EAI were determined by Equations (1) and (2), respectively:

$$
\begin{gathered}
\text { EAI }\left(\mathrm{m}^{2} / \mathrm{g}\right)=\frac{2 \times 2.303 \times \mathrm{A}_{0} \times \mathrm{DF}}{\mathrm{C} \times(1-\theta) \times 10000} \\
\text { ESI }(\mathrm{min})=\frac{\mathrm{A}_{0}}{\mathrm{~A}_{10}} \times 10
\end{gathered}
$$

where DF is the dilution factor, $C$ is the initial concentration of protein $(\mathrm{g} / \mathrm{mL}), \theta$ is the volume fraction of oil in the sample, $A_{0}$ is the absorbance immediately after emulsion formation, and $A_{10}$ is the absorbance at $10 \mathrm{~min}$ following formation of emulsion.

\subsection{Measurement of Protein Concentration in the Emulsion Solutions}

The free protein content in the emulsion was quantified as described previously [46]. Samples were centrifuged at $10,142 \times g$ for $10 \mathrm{~min}$ and $0.2 \mathrm{~mL}$ of the solution was collected from the bottom layer and mixed with $5 \mathrm{~mL} \mathrm{G-250}$ and $0.8 \mathrm{~mL}$ distilled water. The protein concentration was determined with a UV-visible spectrophotometer (Lambda 365, Perkin Elmer Instruments Co., Ltd., Waltham, MA, USA).

\subsection{Protein Flexibility}

The molecular flexibility of the protein extract was evaluated as previously described [41]. Briefly, $250 \mu \mathrm{L}$ of $1.0 \mathrm{mg} / \mathrm{mL}(w / v)$ trypsin solution $(0.05 \mathrm{~mol} / \mathrm{L}$ Tris- $\mathrm{HCl}$ buffer solution, $\mathrm{pH} 8.0)$ was mixed with $4 \mathrm{~mL}$ of $1.0 \mathrm{mg} / \mathrm{mL}(w / v)$ protein solution at $37^{\circ} \mathrm{C}$. After 5 min of reaction, $4 \mathrm{~mL} \mathrm{of} 5 \mathrm{mg} / \mathrm{mL}$ trichloroacetic acid (TCA) was added to the reaction solution to terminate the enzymatic reaction and precipitate the protein. The solution was left to stand for $10 \mathrm{~min}$ before centrifugation at $2200 \times g$ for $15 \mathrm{~min}$. Subsequently, protein flexibility was estimated by measuring the absorbance of supernatant at $280 \mathrm{~nm}$.

\subsection{Measurement of Zeta-Potential and Size Distribution}

After treatment, samples were dispersed in PBS (10 mM, pH 7.2) at $1 \mathrm{mg} / \mathrm{mL}(w / v)$, and then filtered via a $0.45 \mu \mathrm{m}$ cellulose membrane. The filtered samples were transferred into a cell then diluted 10 times using MilliQ water. Particle size and zeta-potential were calculated using a particle size analyzer (Zetasizer ZS-90, Malvern Instruments, Worcestershire, UK).

\subsection{SDS-PAGE}

An SDS-PAGE analysis was performed according to the method published by Zhao et al. with some modifications [47]. The stacking gel and the resolving gel were $5 \%$ and $12 \%$ acrylamide, respectively. Protein samples $(20 \mu \mathrm{L}, 1.0 \mathrm{mg} / \mathrm{mL})$ were mixed with loading buffer containing SDS and $\beta$-mercaptoethanol at 1:1 (v/v). Next, the solutions were boiled for $10 \mathrm{~min}$ and centrifuged. Then, $50 \mu \mathrm{L}$ sample was loaded onto each lane of the SDS-PAGE gel.

Non-reductive gel electrophoresis without $\beta$-mercaptoethanol was performed similar to SDS-PAGE method.

\subsection{UV Spectrum}

The UV absorption capacity of the protein extract was determined as previously described by He et al. [48]. Briefly, we measured the UV spectra of the treated samples and controls $(1.0 \mathrm{mg} / \mathrm{mL}(w / v)$ at 240 to $320 \mathrm{~nm}$ at an interval of $1.0 \mathrm{~nm}$ using Perkin Elmer LAMBDA 365 (Perkin Elmer Instruments 
Co., Ltd., Waltham, MA, USA). The measurements were taken at room temperature with PBS buffer $(10 \mathrm{mM}, \mathrm{pH} 7.2)$ as a blank sample. The second-derivative UV spectra of control and treated protein samples were analyzed with Origin Pro (2017) software (Origin-Lab Co., Northampton, MA, USA).

\subsection{Intrinsic Fluorescence Spectroscopy}

The intrinsic fluorescence spectra of the protein extracts were obtained with a Hitachi F-7000 Fluorescence Spectrophotometer (Hitachi, Ltd., Tokyo, Japan). Samples were dissolved in PBS (10 mM, $\mathrm{pH} 7.2)$ at $0.1 \mathrm{mg} / \mathrm{mL}(w / v)$. The tertiary structure was examined using intrinsic fluorescence emission ranging from 300 to $400 \mathrm{~nm}$ with a $290 \mathrm{~nm}$ excitation under a slit width of $5 \mathrm{~nm}$ for both the excitation and emission slits).

\subsection{FTIR}

The protein samples $(1.0 \mathrm{mg})$ were assorted with $\mathrm{KBr}(100 \mathrm{mg})$ then grounded to a fine powder in an agate mortar under infrared light. The powder was pressed to form a pellet. The FTIR data were obtained at wavenumbers ranging from 400 to $4000 \mathrm{~cm}^{-1}$ over 32 scans with a $4 \mathrm{~cm}^{-1}$ resolution using a PerkinElmer two spectrum (Perkin Elmer Instruments Co., Ltd., Waltham, MA, USA). Data were analyzed with Omnic 8.2 software (Thermo Fisher Scientific Inc., Madison, WI, USA) and Peakfit 4.12 (Systat Software, San Jose, California, USA) [19].

\subsection{Microscopic Examination of the Emulsion}

Samples were diluted 20 times and observed under 400× optical microscope with a XP-213 Transmittance and reverse polarized microscopy (Shanghai Precision Instrument Co., Ltd., Shanghai, China) equipped with a CCD camera.

\subsection{Statistical Analysis}

Data were analyzed and presented using SPSS 22.0 software (SPSS Inc., Chicago, IL, USA), Origin Pro (2017) software (Origin-Lab Co., Northampton, Massachusetts, USA), and Peakfit 4.12 (Systat Software, San Jose, CA, USA). Significant differences between groups were set at $p<0.05$. All experiments were repeated at least thrice.

\section{Conclusions}

Herein, the structure and emulsifying properties of $11 S$ globulin subjected to mild heating, mild heating combined with ultrasound, and ultrasound alone treatments were investigated. Our findings show that ultrasound or ultrasound combined with heating treatments disrupts the solubility and aggregation of proteins into smaller particles and partially unfold 11S globulin. These methods are therefore suitable for modifying the emulsifying properties of $11 \mathrm{~S}$ globulin. This was demonstrated by the disappearance of aggregates in SDS-PAGE analysis and changes in intrinsic fluorescence. Second-derivative UV spectroscopy showed that ultrasound combined with heating increased hydrophobicity and $\alpha$-helix as wells as reduced $\beta$-sheet and uniform-sized protein particles. As a result, the emulsifying activity index was increased 6.49 -folds (from 23.73 to $154.10 \mathrm{~m}^{2} / \mathrm{g}$ ) compared to the control group. Moreover, the structural flexibility and surface charge density of the protein were significantly enhanced, leading to the oil-water interface entirely being distributed by the emulsifier. This improved the emulsifying stability index from 14.12 to $40.93 \mathrm{~min}$.

Author Contributions: Conceptualization: L.L. and J.Z.; methodology: L.L. and J.Z.; software: B.S.; validation: L.L. and J.Z.; formal analysis: L.L.; investigation: B.S. and Y.H.; resources: Y.S.; data curation: L.L. and N.Z.; writing—original draft preparation: L.L.; writing—review and editing: L.L.; visualization: X.Z.; supervision: Y.S.; project administration: X.Z.; funding acquisition: Y.S. All authors have read and agreed to the published version of the manuscript. 
Funding: This research was funded by the National Key Research and Development Program of China (No. 2016YFD0400402), Science and Technology Major Project of Heilongjiang Province (No. 2019ZX08B01) and National Natural Science Foundation (No. 31871747, 31301602).

Acknowledgments: The authors wish to thank the Key Laboratory of Grain Food and Comprehensive Processing of Grain Resource of Heilongjiang Province and the Key Laboratory of Food Science and Engineering of Heilongjiang Province, College of Food Engineering, Harbin University of Commerce.

Conflicts of Interest: The authors declare no conflicts of interest.

\section{References}

1. Liu, Q.; Geng, R.; Zhao, J.; Chen, Q.; Kong, B. Structural and gel textural properties of soy protein isolate when subjected to extreme acid pH-shifting and mild heating processes. J. Agric. Food Chem. 2015, 63, 4853-4861. [CrossRef]

2. Prak, K.; Nakatani, K.; Maruyama, N.; Utsumi, S. C-terminus engineering of soybean proglycinin: Improvement of emulsifying properties. Protein Eng. Des. Sel. 2007, 20, 433-442. [CrossRef]

3. Matsumura, Y.; Sirison, J.; Ishi, T.; Matsumiya, K. Soybean lipophilic proteins: Origin and functional properties as affected by interaction with storage proteins. Curr. Opin. Colloid Interface Sci. 2017, 28, 120-128. [CrossRef]

4. Martínez, K.D.; Carrera Sánchez, C.; Rodríguez Patino, J.M.; Pilosof, A.M.R. Interfacial and foaming properties of soy protein and their hydrolysates. Food Hydrocoll. 2009, 23, 2149-2157. [CrossRef]

5. Morales, R.; Martínez, K.D.; Pizones Ruiz-Henestrosa, V.M.; Pilosof, A.M.R. Modification of foaming properties of soy protein isolate by high ultrasound intensity: Particle size effect. Ultrason. Sonochem. 2015, 26, 48-55. [CrossRef] [PubMed]

6. Zhao, C.B.; Zhou, L.Y.; Liu, J.Y.; Zhang, Y.; Chen, Y.; Wu, F. Effect of ultrasonic pretreatment on physicochemical characteristics and rheological properties of soy protein/sugar maillard reaction products. J. Food Sci. Technol. 2016, 53, 2342-2351. [CrossRef] [PubMed]

7. Wang, X.S.; Tang, C.H.; Li, B.S.; Yang, X.Q.; Li, L.; Ma, C.Y. Effects of high-pressure treatment on some physicochemical and functional properties of soy protein isolates. Food Hydrocoll. 2008, 22, 560-567. [CrossRef]

8. Sharif, H.R.; Williams, P.A.; Sharif, M.K.; Abbas, S.; Majeed, H.; Masamba, K.G.; Safdar, W.; Zhong, F. Current progress in the utilization of native and modified legume proteins as emulsifiers and encapsulants-A review. Food Hydrocoll. 2017, 76, 2-16. [CrossRef]

9. Huang, L.; Ding, X.; Dai, C.; Ma, H. Changes in the structure and dissociation of soybean protein isolate induced by ultrasound-assisted acid pretreatment. Food Chem. 2017, 232, 727-732. [CrossRef]

10. Zhou, M.; Liu, J.; Zhou, Y.; Huang, X.; Liu, F.; Pan, S.; Hu, H. Effect of high intensity ultrasound on physicochemical and functional properties of soybean glycinin at different ionic strengths. Innov. Food Sci. Emerg. 2016, 34, 205-213. [CrossRef]

11. Hu, H.; Cheung, I.W.Y.; Pan, S.; Li-Chan, E.C.Y. Effect of high intensity ultrasound on physicochemical and functional properties of aggregated soybean $\beta$-conglycinin and glycinin. Food Hydrocoll. 2015, 45, 102-110. [CrossRef]

12. Hu, H.; Wu, J.; Li-Chan, E.C.Y.; Zhu, L.; Zhang, F.; Xu, X.; Fan, G.; Wang, L.; Huang, X.; Pan, S. Effects of ultrasound on structural and physical properties of soy protein isolate (SPI) dispersions. Food Hydrocoll. 2013, 30, 647-655. [CrossRef]

13. O'Sullivan, J.; Murray, B.; Flynn, C.; Norton, I. The effect of ultrasound treatment on the structural, physical and emulsifying properties of animal and vegetable proteins. Food Hydrocoll. 2013, 53, 141-154. [CrossRef]

14. Chizoba Ekezie, F.G.; Cheng, J.H.; Sun, D.W. Effects of nonthermal food processing technologies on food allergens: A review of recent research advances. Trends Food Sci. Technol. 2018, 74, 12-25. [CrossRef]

15. Jiang, Z.; Wang, C.; Li, T.; Sun, D.; Gao, H.; Gao, Z.; Mu, Z. Effect of ultrasound on the structure and functional properties of transglutaminase-crosslinked whey protein isolate exposed to prior heat treatment. Int. Dairy J. 2019, 88, 79-88. [CrossRef]

16. Conrad, U.; Fahr, A.; Scriba, G.K.E. Kinetics of aspartic acid isomerization and enantiomerization in model aspartyl tripeptides under forced conditions. J. Pharm. Sci. 2010, 99, 4162-4173. [CrossRef] 
17. Raikos, V. Effect of heat treatment on milk protein functionality at emulsion interfaces. A review. Food Hydrocoll. 2010, 24, 259-265. [CrossRef]

18. Guo, F.; Xiong, Y.L.; Qin, F.; Jian, H.; Huang, X.; Chen, J. Surface properties of heat-induced soluble soy protein aggregates of different molecular masses. J. Food Sci. 2015, 80, C279-C287. [CrossRef]

19. Long, G.; Ji, Y.; Pan, H.; Sun, Z.; Li, Y.; Qin, G. Characterization of thermal denaturation structure and morphology of soy glycinin by FTIR and SEM. Int. J. Food Prop. 2015, 18, 763-774. [CrossRef]

20. Amiri, A.; Sharifian, P.; Soltanizadeh, N. Application of ultrasound treatment for improving the physicochemical, functional, and rheological properties of myofibrillar proteins. Int. J. Biol. Macromol. 2018, 111, 139-147. [CrossRef]

21. Zhang, Q.T.; Tu, Z.C.; Xiao, H.; Wang, H.; Huang, X.Q.; Liu, G.X.; Shi, Y.; Fan, L.L.; Lin, D.R. Influence of ultrasonic treatment on the structure and emulsifying properties of peanut protein isolate. Food Bioprod. Process. 2014, 92, 30-37. [CrossRef]

22. Wu, W.; Wu, X.; Hua, Y. Structural modification of soy protein by the lipid peroxidation product acrolein. J. Sci. Food 2010, 89, 1416-1423. [CrossRef]

23. Wang, J.M.; Yang, X.Q.; Yin, S.W.; Zhang, Y.; Tang, C.H.; Li, B.S.; Yuan, D.B.; Guo, J. Structural rearrangement of ethanol-denatured soy proteins by high hydrostatic pressure treatment. J. Agric. Food Chem. 2011, 59, 7324-7332. [CrossRef] [PubMed]

24. Jiang, J.; Chen, J.; Xiong, Y.L. Structural and emulsifying properties of soy protein isolate subjected to acid and alkaline pH-shifting processes. J. Agric. Food Chem. 2009, 57, 7576-7583. [CrossRef]

25. Lange, R.; Balny, C. UV-visible derivative spectroscopy under high pressure. Biochim. Biophys. Acta 2002, 1595, 80-93. [CrossRef]

26. Kong, J.; Yu, S. Fourier transform infrared spectroscopic analysis of protein secondary structures. Acta Biochim. Biophys. Sin. 2007, 39, 549-559. [CrossRef]

27. Matmaroh, K.; Benjakul, S.; Prodpran, T.; Encarnacion, A.B.; Kishimura, H. Characteristics of acid soluble collagen and pepsin soluble collagen from scale of spotted golden goatfish (Parupeneus heptacanthus). Food Chem. 2011, 129, 1179-1186. [CrossRef]

28. Zhou, C.; Hu, J.; Yu, X.; Yagoub, A.E.A.; Zhang, Y.; Ma, H.; Gan, X.; Otu, P.N.Y. Heat and/or ultrasound pretreatments motivated enzymolysis of corn gluten meal: Hydrolysis kinetics and protein structure. LWT Food Sci. Technol. 2017, 77, 488-496. [CrossRef]

29. Tang, C.H. Nanostructured soy proteins: Fabrication and applications as delivery systems for bioactives (a review). Food Hydrocoll. 2019, 91, 92-116. [CrossRef]

30. Ren, X.; Ma, H.; Mao, S.; Zhou, H. Effects of sweeping frequency ultrasound treatment on enzymatic preparations of ACE-inhibitory peptides from zein. Eur. Food Res. Technol. 2014, 238, 435-442. [CrossRef]

31. Gülseren, İ.; Güzey, D.; Bruce, B.D.; Weiss, J. Structural and functional changes in ultrasonicated bovine serum albumin solutions. Ultrason. Sonochem. 2007, 14, 173-183. [CrossRef] [PubMed]

32. Jin, J.; Ma, H.; Wang, K.; Yagoub, A.E.-G.A.; Owusu, J.; Qu, W.; He, R.; Zhou, C.S.; Ye, X. Effects of multi-frequency power ultrasound on the enzymolysis and structural characteristics of corn gluten meal. Ultrason. Sonochem. 2015, 24, 55-64. [CrossRef] [PubMed]

33. Xiong, W.; Wang, Y.; Zhang, C.; Wan, J.; Shah, B.R.; Pei, Y.; Zhou, B.; Li, J.; Li, B. High intensity ultrasound modified ovalbumin: Structure, interface and gelation properties. Ultrason. Sonochem. 2016, 31, 302-309. [CrossRef] [PubMed]

34. Adachi, M.; Takenaka, Y.; Gidamis, A.B.; Mikami, B.; Utsumi, S. Crystal structure of soybean proglycinin A1aB1b homotrimer. J. Mol. Biol. 2001, 305, 291-305. [CrossRef] [PubMed]

35. Jiang, L.; Wang, J.; Li, Y.; Wang, Z.; Liang, J.; Wang, R.; Chen, Y.; Ma, W.; Qi, B.; Zhang, M. Effects of ultrasound on the structure and physical properties of black bean protein isolates. Food Res. Int. 2014, 62, 595-601. [CrossRef]

36. Arzeni, C.; Martínez, K.; Zema, P.; Arias, A.; Pérez, O.E.; Pilosof, A.M.R. Comparative study of high intensity ultrasound effects on food proteins functionality. J. Food Eng. 2012, 108, 463-472. [CrossRef]

37. Güzey, D.; Gülseren, I.; Bruce, B.; Weiss, J. Interfacial properties and structural conformation of thermosonicated bovine serum albumin. Food Hydrocoll. 2006, 20, 669-677. [CrossRef]

38. Zhang, L.; Pan, Z.; Shen, K.; Cai, X.; Zheng, B.; Miao, S. Influence of ultrasound-assisted alkali treatment on the structural properties and functionalities of rice protein. J. Cereal Sci. 2018, 79, 204-209. [CrossRef] 
39. Tang, C.H. Emulsifying properties of soy proteins: A critical review with emphasis on the role of conformational flexibility. Crit. Rev. Food Sci. 2017, 57, 2636-2679. [CrossRef]

40. Kato, A.; Ibrahim, H.R.; Watanabe, H.; Honma, K.; Kobayashi, K. Structural and gelling properties of dry-heated egg white proteins. J. Agric. Food Chem. 1990, 38, 32-37. [CrossRef]

41. Li, R.; Wang, X.; Liu, J.; Cui, Q.; Wang, X.; Chen, S.; Jiang, L. Relationship between molecular flexibility and emulsifying properties of soy protein isolate-glucose conjugates. J. Agric. Food Chem. 2019, 67, 4089-4097. [CrossRef] [PubMed]

42. Wu, J.; Fan, Q.; Xia, Y.; Ma, G. Uniform-sized particles in biomedical field prepared by membrane emulsification technique. Chem. Eng. Sci. 2015, 125, 85-97. [CrossRef]

43. Li, K.; Kang, Z.L.; Zhao, Y.Y.; Xu, X.L.; Zhou, G.H. Use of high-intensity ultrasound to improve functional properties of batter suspensions prepared from PSE-like chicken breast meat. Food Bioprocess Technol. 2014, 7, 3466-3477. [CrossRef]

44. Johnson, E.A.; Brekke, C.J. Functional properties of acylated pea protein isolates. J. Food Sci. 1983, 48, 722-725. [CrossRef]

45. Makeri, M.U.; Mohamed, S.A.; Karim, R.; Ramakrishnan, Y.; Muhammad, K. Fractionation, physicochemical, and structural characterization of winged bean seed protein fractions with reference to soybean. Int. J. Food Prop. 2017, 20, 2220-2236. [CrossRef]

46. Berton, C.; Genot, C.; Ropers, M.H. Quantification of unadsorbed protein and surfactant emulsifiers in oil-in-water emulsions. J. Colloid Interface Sci. 2011, 354, 739-748. [CrossRef]

47. Zhao, J.; He, S.; Tang, M.; Sun, X.; Zhang, Z.; Ye, Y.; Sun, H. Low-pH induced structural changes, allergenicity and in vitro digestibility of lectin from black turtle bean (Phaseolus vulgaris L.). Food Chem. 2019, 283, 183-190. [CrossRef]

48. He, S.; Simpson, B.; Ngadi, M.; Xue, S.; Shi, J.; Ma, Y. pH stability study of lectin from black turtle bean (phaseolus vulgaris) as influenced by guanidinium- $\mathrm{HCl}$ and thermal treatment. Protein Pept. Lett. 2015, 22, 45-51. [CrossRef]

Sample Availability: Samples of the compounds are available from the authors.

(C) 2020 by the authors. Licensee MDPI, Basel, Switzerland. This article is an open access article distributed under the terms and conditions of the Creative Commons Attribution (CC BY) license (http://creativecommons.org/licenses/by/4.0/). 